\title{
A Case of Adrenal Sex Hormone Imbalance in a Dog
}

\author{
V. BRUNCLÍK ${ }^{1}$, J. KOLEVSKÁ ${ }^{1}$, L. BARTOŠOVÁ ${ }^{2}$
}

\begin{abstract}
${ }^{1}$ Clinic of Dog and Cat Diseases, Faculty of Veterinary Medicine, University of Veterinary and Pharmaceutical Sciences, Brno, Czech Republic ${ }^{2}$ Department of Human Pharmacology and Toxicology, Faculty of Pharmacy, University of Veterinary and Pharmaceutical Sciences, Brno, Czech Republic
\end{abstract}

Received April 28, 2005

Accepted August 30, 2005

\begin{abstract}
Brunclík V., J. Kolevská, L. Bartošová: A Case of Adrenal Sex Hormone Imbalance in a Dog. Acta Vet. Brno 2005, 74: 411-417.

This paper describes a case of a two-year-old male Pomeranian which was, on the basis of physical examination, laboratory findings and the results of skin biopsy, diagnosed with hormoneresponsive dermatosis. With the help of other hormonal tests its disease was specified as a sex hormone imbalance. The therapeutic castration of the dog was carried out which only led to a temporal improvement. The final diagnosis, with respect to the course of disease, was defined as an adrenal-dependent sex hormone imbalance. Lysodren therapy was initiated, leading to a complete and permanent disappearance of the patient's symptoms.
\end{abstract}

Congenital adrenal hyperplasia-like syndrome, dog, mitotane

Adrenal-dependent sex hormone imbalance is a rarely occurring endocrine disease which has been described in certain breeds of dogs: Pomeranian, Chow-Chow, Samoyed, Toy Poodle. Dermatologic manifestations (symmetric truncal alopecia) most frequently imitating hyposomatotropism and gonadal-dependent sex hormone imbalance are the symptoms of this disease. This disease usually does not affect the general state of the patient's health (Lothrop 1988; Scott et al. 1995; Feldman and Nels on 2004).

In case of the affected dogs of the above mentioned breeds, it concerns the defect of one of the adrenal enzymes (11- $\beta$ hydroxylase, 21-hydroxylase or 3- $\beta$ hydroxysteroid dehydrogenase) which results in a partial defect as far as the synthesis of cortisol and aldosterone is concerned (Schmeitzel and Lothrop 1990). This disorder is functionally substituted by an increased production of ACTH and by a hyperplasia of adrenal tissue, so a sufficient amount of cortisol and mineralocorticoids is produced. This process does not lead to insufficiency. However, the cost for this is an excessively increased production of adrenal steroids (Feldman and Nelson 2004). Exceptionally, a moderate overproduction of glucocorticoids can appear, leading to Cushing's syndrome (Rijnberk 1996).

In case of this specific breed (the Pomeranian), the disease brings about the deficiency of particularly 21-hydroxylase with stagnating transformation of progesterone to 11deoxycorticosteron and $17 \alpha$-hydroxyprogesteron to 11-deoxycortisol. In their study, Schmeitzel and Lothrop (1990) determined the concentration of $17 \alpha-$ hydroxyprogesteron, dehydroepiandrosteron and androstendion (direct precursor of estrogen) specifically for dogs of this breed. They managed to document a significant increase of these hormones present in comparison to a control group of dogs of different breeds. In this study, the authors also mention that such changes were not clinically manifested in all the dogs with this enzyme deficiency. On the other hand there are authors who exclude the mutation of the 21-hydroxylase gene as a possible cause of the adrenal sex hormone imbalance in the Pomeranian (Takada et al. 2002).

\footnotetext{
Address for correspondence:

MVDr. Jana Kolevská, Ph.D

Clinic of Dog and Cat Diseases

Faculty of Veterinary Medicine

University of Veterinary and Pharmaceutical Sciences, Palackého 1-3

61242 Brno, Czech Republic
}

Mob.: 602771872

E-mail:kolevskaj@email.cz

http://www.vfu.cz/acta-vet/actavet.htm 
Similar congenital defects were also depicted in humane medicine - Eberlein and Bongiovanni's syndrome, Prader-Siebann's syndrome (Stárka a Zamrazil 1997).

The present paper describes the course of the above mentioned disease of a two-year-old Pomeranians.

\section{Materials and Methods}

Physical examination

A two-year-old male Pomeranian was presented at the Clinic of Dog and Cat Diseases, Faculty of Veterinary Medicine, Veterinary and Pharmaceutical University Brno. A complete physical examination of the patient was carried out.

Laboratory examinations

Blood samples were collected and preserved with EDTA prior to haematological examination with Beckman coulter ACT 8. Differential blood count was evaluated after staining with standard May-Grünwald and GiemsaRomanowski stains. Biochemical examination was carried out in serum after standard centrifugation. Cobas Mira $\mathrm{S}$ analyser was used to determine biochemical parameters. Cortisol, total thyroxine (tT4), free thyroxine (fT4), canine thyrotropin (cTSH), estradiol, progesterone and testosterone levels in serum were determined by chemiluminiscence immunoanalysis (Immulite 2000 Estradiol, Progesterone, Total Testosterone, Total T4, Free T4 and Immulite cTSH, Diagnostic Products Corporation). Sensitivity of estradiol determination was $37 \mathrm{pmol} / 1$, progesterone $06 \mathrm{nmol} / 1$, total testosterone $0.3 \mathrm{nmol} / 1$, total thyroxine $5 \mathrm{nmol} / 1$, free thyroxine $2.3 \mathrm{pmol} / 1$, $\mathrm{cTSH}$ $0.03 \mathrm{ng} / \mathrm{ml}$. Calibration range upper limit was $7342 \mathrm{pmol} / 1$ (estradiol), $127 \mathrm{nmol} / 1$ (progesterone), $55 \mathrm{nmol} / 1$ (total testosterone), $309 \mathrm{nmol} / \mathrm{l}$ (total thyroxine), $77.2 \mathrm{pmol} / 1$ (free thyroxine), $12 \mathrm{ng} / \mathrm{ml}$ (cTSH).

The Low-Dose Dexamethasone test for the hyperadrenocorticism was performed and the urine cortisol/creatinine ratio measured (Rijnberk et al. 1988).

Immunoreactive cortisol levels in urine were measured using the method of fluorescence polarisation immunoassay - FPIA (TDx system) with urine extraction (Abbott comp., No 9116-60). Dichlormethan was used for urine extraction. Creatinine levels were measured in each sample urine, too. The results obtained were used to compute the urine cortiol/creatinine ratio (UCCR).

The skin biopsy was carried out. Tissue specimens were fixed in formalin, routinely processed and paraffin embedded. The slides were stained with haematoxylin and eosin.

Therapy

The patient was treated with o,p'DDD (Lysodren ${ }^{\circledR}$, Bristol Laboratories). The therapeutic protocol of selective adrenocorticolysis was used (Scott et al. 1995).

\section{Results}

In November 2001 a patient (two-year-old Pomeranian, male, $2 \mathrm{~kg}$ body weight) was presented at the Clinic of Dog and Cat Diseases with the following anamnesis. In February this patient underwent an operation (Anal Sac Fistula), after clipping the skin remained bare, without hair. The hair coat of the presented patient was of low quality, imbricated, mildly hyperpigmented with apparent frayed and brittle hair tips (Plates VIII, IX, Figs 1-3). The owner of the patient did not claim the presence of pruritus. Dermatological examination was carried out, and blood taken for basic haematological and biochemical tests. Skin scraping test proved negative, and the haematological and biochemical test results did not display any noticeable differences from the reference range (Table 1). After the skin biopsy, the result of the dermatohistopathologic examination was following: Epidermis - mild basket weave hyperkeratosis, epidermal atrophy in the whole range (only 1 layer, maximum of 2 layers of proliferating skin cells). Dermis - on the whole thinner, collagen fibres' scarce and of lighter colour. Adnexa - atrophy, dilatation, keratosis of follicles, intact follicles, predominance of telogen hair follicles, and great number of follicles demonstrating trichilemmal keratinization (flame fibres). Otherwise normal histopathological finding. Subcutis normal finding. Final result of skin biopsy - atrophic hormonal dermatosis.

The dermatological examination findings considered, the next diagnostic step of hormonal tests was taken. Repeatedly parallel concentration of total thyroxine $\left(\mathrm{tT}_{4}\right)$, free thyroxine $\left(\mathrm{fT}_{4}\right)$ and canine thyrotropin (cTSH) was measured. The Low-Dose Dexamethasone test followed, UCCR and basal concentration of estradiol, progesterone and testosterone were determined. Concentrations of $\mathrm{tT}_{4}, \mathrm{fT}_{4}$ and $\mathrm{cTSH}$ proved to be 
Table 1. Haematological and biochemical values in the dog presented for examination in November 2001

\begin{tabular}{|c|c|c|}
\hline Parameter (unit) & Presented Patient & Reference range \\
\hline Haemoglobin $(g / 1)$ & 162 & $120-180$ \\
\hline Haematocrit (1/1) & 0.49 & $0.37-0.55$ \\
\hline Erythrocytes $\left(10^{12} / 1\right)$ & 7.42 & $5.4-8$ \\
\hline Leukocytes $\left(10^{9} / 1\right)$ & 9.2 & $6-18$ \\
\hline Neutrophils bands $\left(10^{9} / 1\right)$ & 0.184 & $0-1$ \\
\hline Neutrophils mature $\left(10^{9} / 1\right)$ & 5.428 & $3-11.4$ \\
\hline Lymphocytes $\left(10^{9} / 1\right)$ & 3.312 & $0.8-3.8$ \\
\hline Monocytes $\left(10^{9} / 1\right)$ & 0.184 & $0-1.8$ \\
\hline Eosinophils $\left(10^{9} / 1\right)$ & 0.092 & $0-1.9$ \\
\hline Total protein $(\mathrm{g} / \mathrm{l})$ & 59.7 & $55-75$ \\
\hline Albumin $(\mathrm{g} / \mathrm{l})$ & 29.3 & $23-34$ \\
\hline Glucose (mmol/l) & 5.2 & $3.3-7.0$ \\
\hline Creatinine $(\mu \mathrm{mol} / \mathrm{l})$ & 50.6 & $20-110$ \\
\hline Urea $(\mathrm{mmol} / \mathrm{l})$ & 8.5 & $3-9$ \\
\hline $\operatorname{ALP}(\mu \mathrm{kat} / \mathrm{l})$ & 1.32 & $0.1-1.5$ \\
\hline $\operatorname{ALT}(\mu \mathrm{kat} / \mathrm{l})$ & 0.65 & $0-1$ \\
\hline $\operatorname{AST}(\mu \mathrm{kat} / 1)$ & 0.58 & $0-1$ \\
\hline Triglycerides $(\mathrm{mmol} / \mathrm{l})$ & 0.86 & $0.5-1.7$ \\
\hline Cholesterol (mmol/l) & 4.34 & $2.7-7$ \\
\hline Sodium $(\mathrm{mmol} / \mathrm{l})$ & 145 & $140-158$ \\
\hline Potassium (mmol/1) & 4.2 & $3.8-5.8$ \\
\hline Calcium $(\mathrm{mmol} / \mathrm{l})$ & 2.7 & $2.2-2.9$ \\
\hline Phosphorus (mmol/l) & 1.8 & $0.5-2.6$ \\
\hline Estradiol (pmol/1) & 338 & $<200$ (male dogs) \\
\hline Progesterone $(\mathrm{nmol} / \mathrm{l})$ & 2.8 & $<2.7$ (male dogs) \\
\hline Total testosterone $(\mathrm{nmol} / \mathrm{l})$ & 8.7 & $<25$ (male dogs) \\
\hline Canine thyrotropin $(\mathrm{ng} / \mathrm{ml})$ & 0.28 & $0.03-1.0$ \\
\hline Free thyroxine $(\mathrm{pmol} / \mathrm{l})$ & 21.5 & $<10$ \\
\hline Total thyroxine (nmol/1) & 29 & $20-40$ \\
\hline $\mathrm{UCCR} \times 10^{-6}$ & 5.16 & $<10$ \\
\hline
\end{tabular}

within reference range, UCCR was in between $3-5 \times 10^{-6}$, the Low-Dose Dexamethasone test showed negative result, and the basal concentration of estradiol and progesterone was repeatedly found increased, considering the animal was male. The treatment recommended for the patient and subsequently completed in February 2002 was castration. Histopathological examination of testes did not prove any pathological findings.

In May the patient had a check-up, the owner stated considerable improvement, the dog almost covered with hair, the quality of hair distinctly improved. When tested again, the sex hormone (estradiol, progesterone, testosterone) levels significantly decreased (Table 2 ). The owner then discontinued contact.

The patient reappeared in January 2004, showing almost the same dermatological symptoms, which however were of a more striking character than before castration and their intensity was on increase. Again a series of examinations was carried out: haematological and biochemical examinations and hormonal tests (parallel determination of $\mathrm{tT}_{4}, \mathrm{fT}_{4}$ and cTSH concentration, UCCR, Low-Dose Dexamethasone test, and basal concentration of estradiol and progesterone). The results were almost identical with those of the first visit findings of the patient. Significant differences from the norm (increase) were found only 
Table 2. Serum concentrations of sex hormones three months after castration (April 2002)

\begin{tabular}{|l|c|c|}
\hline Parameter (unit) & Presented patient & Reference range \\
\hline Estradiol (pmol/l) & 148 & $<230$ \\
\hline Progesterone $(\mathrm{nmol} / \mathrm{l})$ & 0.63 & $<2.2$ \\
\hline Total testosterone $(\mathrm{nmol} / \mathrm{l})$ & $<0.69$ & $0-15$ \\
\hline
\end{tabular}

Table 3. Haematological and biochemical values in the dog presented for examination in January 2004

\begin{tabular}{|c|c|c|}
\hline Parameter (unit) & Presented Patient & Reference range \\
\hline Haemoglobin $(g / 1)$ & 141 & $120-180$ \\
\hline Haematocrit (1/1) & 0.43 & $0.37-0.55$ \\
\hline Erythrocytes $\left(10^{12} / 1\right)$ & 6.28 & $5.4-8.0$ \\
\hline Leukocytes $\left(10^{9} / 1\right)$ & 9.2 & $6-18$ \\
\hline Neutrophils bands $\left(10^{9} / 1\right)$ & 0.276 & $0-1$ \\
\hline Neutrophils mature $\left(10^{9} / 1\right)$ & 5.428 & $3-11.4$ \\
\hline Lymphocytes $\left(10^{9} / 1\right)$ & 2.392 & $0.8-3.8$ \\
\hline Monocytes $\left(10^{9} / 1\right)$ & 0.276 & $0-1.8$ \\
\hline Eosinophils $\left(10^{9} / 1\right)$ & 0.828 & $0-1.9$ \\
\hline Total protein $(\mathrm{g} / \mathrm{l})$ & 60 & $55-75$ \\
\hline Albumin $(g / l)$ & 27 & $23-34$ \\
\hline Glucose (mmol/l) & 5.5 & $3.3-7$ \\
\hline Creatinine $(\mu \mathrm{mol} / \mathrm{l})$ & 97.7 & $20-110$ \\
\hline Urea $(\mathrm{mmol} / \mathrm{l})$ & 8 & $3-9$ \\
\hline $\operatorname{ALP}(\mu \mathrm{kat} / 1)$ & 2.4 & $0.1-2.5$ \\
\hline $\operatorname{ALT}(\mu \mathrm{kat} / \mathrm{l})$ & 0.7 & $0-1$ \\
\hline $\operatorname{AST}(\mu \mathrm{kat} / 1)$ & 0.5 & $0-1$ \\
\hline Triglycerides $(\mathrm{mmol} / \mathrm{l})$ & 0.6 & $0.5-1.7$ \\
\hline Cholesterol (mmol/l) & 3.5 & $2.7-7.0$ \\
\hline Sodium $(\mathrm{mmol} / \mathrm{l})$ & 148 & $140-158$ \\
\hline Potassium (mmol/1) & 4.3 & $3.8-5.8$ \\
\hline Calcium $(\mathrm{mmol} / \mathrm{l})$ & 2.5 & $2.2-2.9$ \\
\hline Phosphorus (mmol/1) & 0.8 & $0.5-2.6$ \\
\hline Estradiol (pmol/1) & 585 & $<200$ (male dogs) \\
\hline Progesterone (nmol/1) & 1.3 & $<2.7$ (male dogs) \\
\hline Total testosterone $(\mathrm{nmol} / \mathrm{l})$ & $<0.69$ & $<25$ (male dogs) \\
\hline Total thyroxine $(\mathrm{nmol} / \mathrm{l})$ & 39.1 & $20-40$ \\
\hline Free thyroxine (pmol/1) & 18.8 & $<10$ \\
\hline Canine thyrotropin (ng/ml) & 0.24 & $0.03-1$ \\
\hline $\mathrm{UCCR} \times 10^{-6}$ & 3.2 & $<10$ \\
\hline
\end{tabular}

with the estradiol concentration, these were within the range from 474 to $584 \mathrm{pmol} / \mathrm{l}$. Considering the course of disease (a temporary reaction to therapeutic castration) and hormonal test results, the final diagnosis determined the disease as an adrenal-dependent sex hormone imbalance.

The available therapy alternatives were proposed to the owner, and comparisons of their effectiveness were provided in detail, including descriptions of possible risks and undesirable side effects. The Lysodren therapy was recommended as the most effective method of treatment for this disease. The owner agreed, given the risk analysis, and in February 2004 the Lysodren therapy was initiated. The initial Lysodren dosage of 15 $\mathrm{mg} / \mathrm{kg} /$ day was divided and given 4 times daily during the first fortnight. It was then 
increased to $25 \mathrm{mg} / \mathrm{kg}$ and also divided and given 4 times daily, always with food. Monitoring of the patient consisted of determining UCCR (minimalization of the risk of iatrogenic hypoadrenocorticism) and defining basal concentration of estradiol and progesterone, both twice a week. After 34 days of therapy there was a sudden and significant decrease of UCCR (under $1 \times 10^{-6}$ ) and the concentration of estradiol also began to decrease. No symptoms of glucocorticoid of mineralocortikoid deficiency were present, nevertheless the therapy was discontinued for 14 days. After it maintenance doses of Lysodren-25kg/mg were administered once a week.

Six weeks after the beginning of therapy, the dog's hair started to grow normally, and after four months a complete hair coat was restored (Plate IX, Figs 4, 5). According to the owner, the dog is now indistinguishable from other dog of the same breed (from a different litter), which does not suffer from any dermatological symptoms and has won a number of exhibition prizes since. At present the dog is medicated with the same dose of Lysodren once a week divided and given twice daily and control monitoring (determining UCCR and the concentration of sex hormones) is carried out once in 3 to 4 months.

\section{Discussion}

Dermatological manifestations of the sex hormone imbalance are identical and do not depend on the place of their origin (adrenal/gonadal source of disease). They are demonstrated by symmetric, primarily non-pruritic alopecia that begins in the perineal, genital, and ventral abdominal regions and spreads cranially. The skin is dry, hyperpigmented with seborrhoea often present, the hairs fall out easily and after clipping do not regrow. Additional clinical symptoms depend on the underlying etiology. In males, the symptoms of gonadal sex hormone imbalance in connection with hyperestrogenism (Sertoli cell tumour) may include gynaecomastia, galactorrhoea, a pendulous prepuce, and attraction of other male dogs. Females with gonadal hyperestrogenism often have signs of vulvar enlargement, persistent proestrus or estrus (Feldman and Nelson 2004). Adrenal-dependent sex hormone imbalance is an endocrine disease with mainly dermatologic clinical symptoms. These symptoms usually do not affect the general state of patient's health although in the final phase of the disease, they can be of a very serious character. In this case the clinical symptoms corresponded to the above described ones. This patient was presented with a primarily non-pruritic alopecia near the genitals, further spreading cranially. Both seborrhoea and hyperpigmentation were present. The patient was otherwise healthy.

The final diagnosis of the sex hormone imbalance can be based on the signalment, history, and physical examination findings, and the biochemical and hormonal tests, done to rule out other sources of endocrine diseases (Frank et al. 2001). Great importance for determining the final diagnosis also lies in responses to therapy. The histopathologic examination signs show changes that are typical changes of the hormonal dermatosis but they can at the same time represent follicular dysplasia (Feldman and Nels on 2004). The determination of sex hormones (mainly estradiol and progesterone) and their precursors is further recommended. If no differences in basal concentration are apparent, it is advisable to measure the concentration before as well as after the application of the adrenocorticothropic hormone (Schmeitzel and Lothrop 1990; Scott et al. 1995). In case of the patient, the results of the above mentioned hormonal tests proved the concentration of estradiol and progesterone to be significantly increased. Other results were within the reference range, thus allowing us to rule out the presence of any other endocrine diseases.

Adrenal-dependent sex hormone imbalance therapy involves castration. However, its effect is usually only temporary (sometimes even imperfect). Other therapy alternatives involve the indication of metyltestosterone, growth hormone, melatonin or mitotane 
(Lysodren). Mitotane is reportedly the most effective therapy for this disease because it causes necrosis and atrophy of zona fasciculata and zona reticularis of the adrenal cortex (Rosenkrantz and Griffin 1992; Feldman and Nelson 2004). Our patient underwent a therapeutic castration leading to hair coat recovery and disappearance of the clinical symptoms for a few months. When the symptoms reappeared, Lysodren was introduced in generally recommended doses of 15 - $25 \mathrm{mg} / \mathrm{kg} /$ day (Rosenkrantz and Griffin 1992; Feldman and Nels on 2004). Monitoring of the glucocorticoid production was performed, drawing on UCCR, same as in case of Cushing's syndrome therapy (Galac et al. 1997; Rijnberk 1988; Van Vonderen et al. 1998). The aim of such monitoring was to minimalize the risk of the iatrogene hypoadrenocorticism. While some authors do not consider UCCR to be a suitable method for monitoring the production of glucocorticoids during the therapy (Smiley and Peterson 1993; Reusch 2005), others claim it to be a highly sensitive method as long as the patient's stress stimuli are eliminated (Van Vonderen et al. 1998). The length of the initial therapy was defined on the basis of repetitive monitoring of the basal concentration of estradiol, progesterone and UCCR. The same methods were used to determine the dosages of Lysodren during the maintenance therapy.

No complications appeared during the Lysodren therapy. Although during the initial therapy the UCCR decreased under the limits of detection, the patient did not show any signs of hypoadrenocorticism and during 14 days after the Lysodren therapy was discontinued the production of glucocorticoids was stabilized. In this case the length of the initial therapy was above the upper limit of the reported data in literature, which draw on the experience of patients suffering from central hyperadrenocorticism, where the therapeutic protocol is similar. Reusch (2005) states that around $90 \%$ of dogs with central hyperadrenocorticism react to the Lysodren therapy in dosages of $50 \mathrm{mg} / \mathrm{kg} /$ day within 5 to 9 days and with most of them the production of cortisol is decreased to the reference range within 14 days. At present, the patient is stabilized and medicated with a maintenance Lysodren dosage of $25 \mathrm{mg} / \mathrm{kg}$ administered once a week, in accord with the published data (Feldman and Nelson 2004; Reusch 2005).

Adrenal dependent sex hormone imbalance prognosis is good, even without therapy. With respect to the fact that this disease mostly does not affect the general state of patient's health and is solely a matter of appearance. The dogs with the above described disease live to the same age, no matter whether they go through the therapy or not. The quality of their lives is not significantly disturbed.

If the patient, as a consequence to compensatory mechanisms, is secondary affected by the overproduction of glucocorticoids (minority of cases), the situation changes and the therapy is inevitable. If we accede to the therapy (either for aesthetic reasons or because of hyperadrenocorticism), the regular hormone monitoring is necessary to eliminate the risk of iatrogenic hypoadrenocorticism (Feldman and Nels on 2004).

\section{Adrenální dysfunkce pohlavních hormonů u psa - kazuistika}

Práce popisuje př́ipad dvouletého pomořanského špice samčího pohlaví, u kterého byla na základě klinického vyšetření, laboratorních vyšetření a výsledkủ kožní biopsie stanovena diagnóza hormonální dermatóza. S pomocí dalších hormonálních testů byla specifikována jako dysbalance pohlavních hormonů. U psa se přistoupilo terapeuticky ke kastraci, která vedla pouze $\mathrm{k}$ dočasnému zlepšení. Definitivní diagnóza byla, vzhledem $\mathrm{k}$ průběhu onemocnění, uzavřena jako adrenální dysfunkce pohlavních hormonů. U psa byla zahájena terapie Lysodrenem, která vedla k úplnému a trvalému vymizení klinických obtižži.

\section{Acknowledgements}

The authors wish to thank MVDr. Jan Rybníček for his dermatohistopathological evaluation. 


\section{References}

FELDMAN EC, NELSON RW 2004: Disorders that resemble GH-responsive dermatosis. In: FELDMAN EC, NELSON RW. Canine and Feline Endocrinology and Reproduction. W.B. Saunders Comp., Philadelphia, pp. 64-69

FRANK LA, SCHMEITZEL LP, OLIVER JW 2001: Steroidogenic response of adrenal tissues after administration of ACTH to dogs with hypercortisolemia. J Amer Vet Med Assoc 218: 214-216

GALAC S, KOOISTRA HS, TESKE E, RIJBERK A 1997: Urinary corticoid/creatinine ratios in the differentiation between pituitary-dependent hyperadrenocorticism and hyperadrenocorticism due to adrenocortical tumour in the dog. Vet Quart 19: 17-20

LOTHROP CD 1988: Pathophysiology of canine growth hormone - responsive alopecia. Compend Contin Educ Pract Vet 10: 1346-1349

REUSCH CE 2005: Hyperadrenocorticism. In: ETTINGER SE, FELDMAN EC (eds): Textbook of Veterinary Internal Medicine, 6th ed. W.B. Saunders Comp., Philadelphia, pp. 1592-1612

RIJNBERK A 1996: Adrenocortical hyperfunction; Cushing's syndrome. In: RIJBERK A. Clinical Endocrinology of dogs and Cats. Kluwer Academic Publishers, Dordrecht, pp. 73-91

RIJNBERK A 1996: Acquired disturbances of growth hormone release (many unresolved questions). In: RIJNBERK A: Clinical Endocrinology of Dogs and Cats. Kluwer Academic Publishers, Dordrecht, pp. 20-22

RIJNBERK A, WEES A, MOL JA 1988: Assessment of two tests for the diagnosis of canine hyperadrenocorticism. Vet Rec 122: 178-180

ROSENKRANTZ WS, GRIFFIN C 1992: Lysodren therapy in suspect adrenal sex hormone dermatosis. Proceedings of the Second World Congress of Veterinary Dermatology, Montreal, Canada, May, pp. 121-125

SCHMEITZEL LP, LOTHROP CD 1990: Hormonal abnormalities in Pomeranians with normal coat and in Pomeranians with growth hormone-responsive dermatosis. J Amer Vet Med Assoc 197: 1333-1341

SCOTT DW, MILLER WH, GRIFFIN CE 1995: Adrenal sex hormone imbalance. In: SCOTT DW, MILLER WH, GRIFFIN CE: Small Animal Dermatology. W. B. Saunders Comp., Philadelphia, pp. 688-690

SMILEYLE, PETERSON ME 1993: Evaluation of a urine cortisol : creatinine ratio as a screening test for hyperadrenocorticism in dogs. J Vet Int Med 7: 163-168

STÁRKA L, ZAMRAZIL V 1997: Metabolické poruchy steroidogeneze a disociace adrenálních funkcí-steroidní enzymopatie. In: STÁRKA L. Endokrinologie. Maxdorf, Praha, pp. 152-159

TAKADA K, KITAMURA H, TAKIGUCHI M, SAITO M, HASHIMOTO A 2002: Cloning of canine 21hydroxylase gene and its polymorphic analysis as a candidate gene for congenital adrenal hyperplasia-like syndrome in Pomeranians. Res Vet Sci 73: 159-163

VAN VONDEREN IK, KOOISTRA HS, RIJNBERK A 1998: Influence of veterinary care on the urinary corticoid:creatinine ratio in dogs. J Vet Int Med 12: 431-435 
Plate VIII

Brunclík V. et al.: A case of adrenal ... pp. 411-417

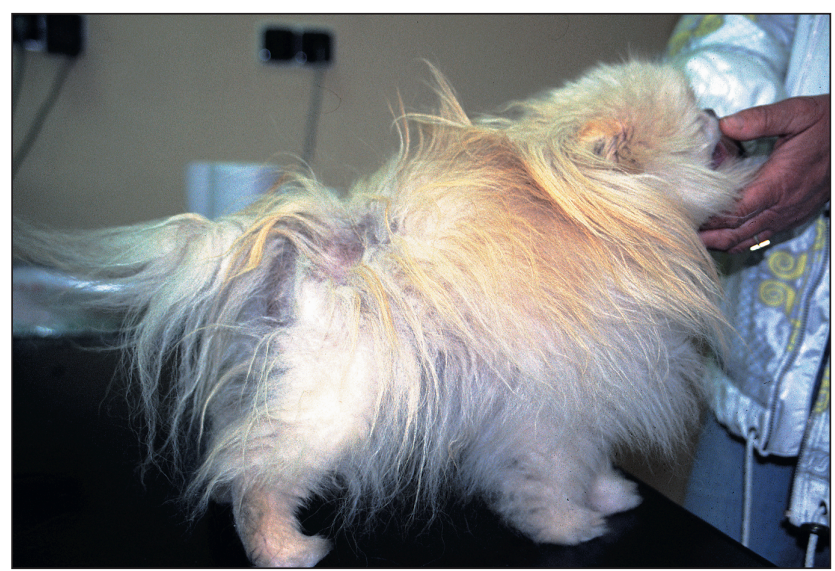

Figs. 1 - 3: Symmetric, non-pruritic alopecia with dry, hyperpigmented skin in presented patient before mitotane therapy.

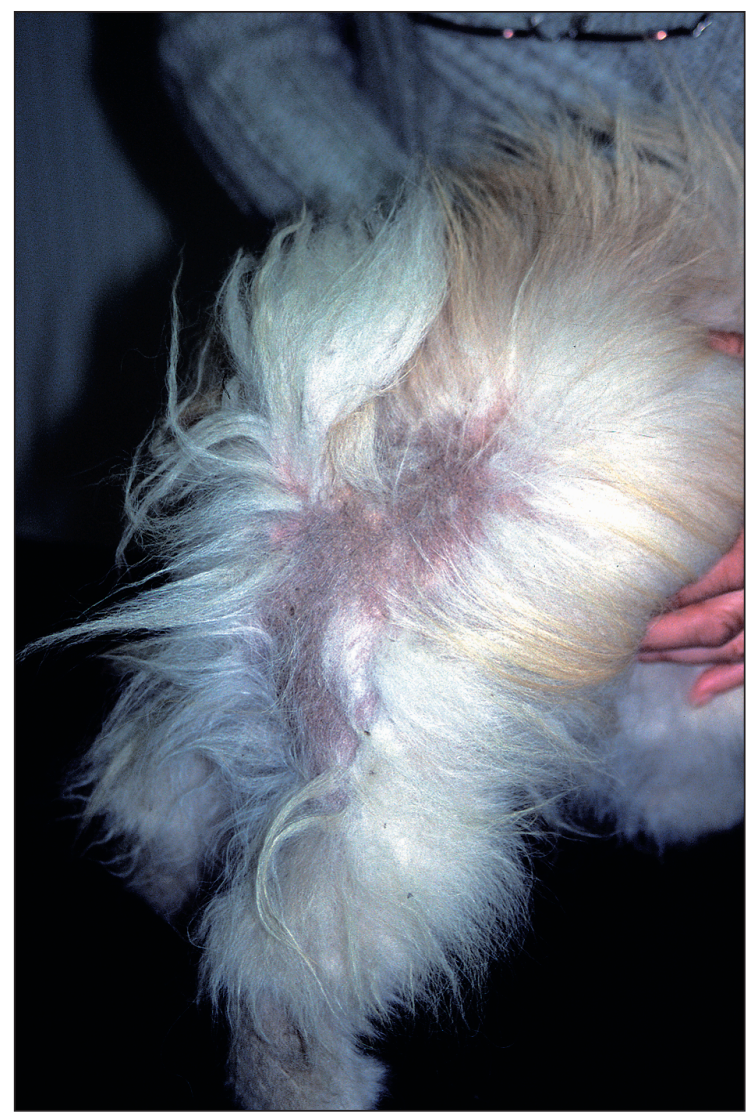

Fig 2. 
Plate IX

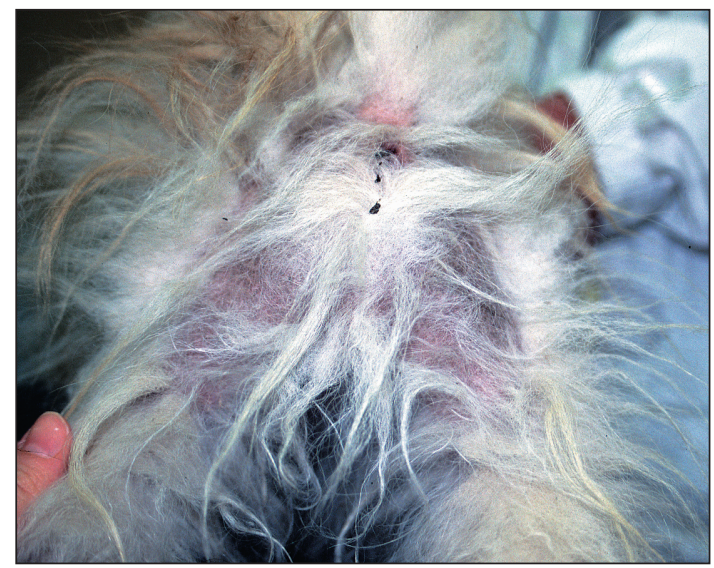

Fig. 3. Patient before mitotane therapy

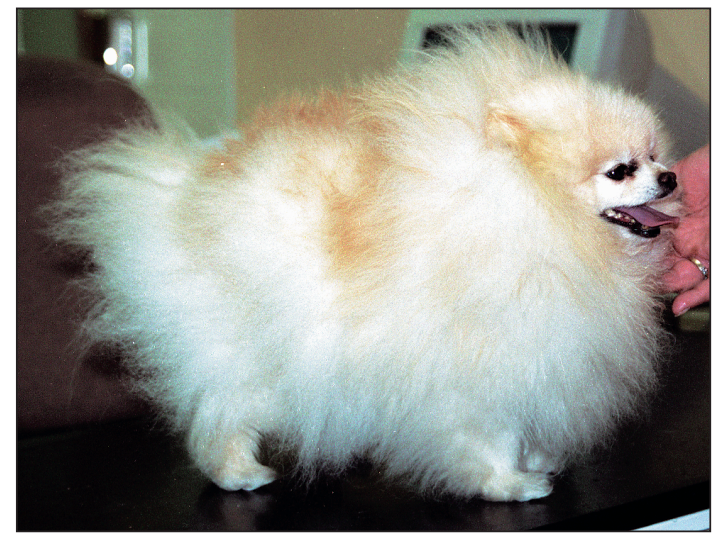

Fig. 4. Patient after mitotane therapy

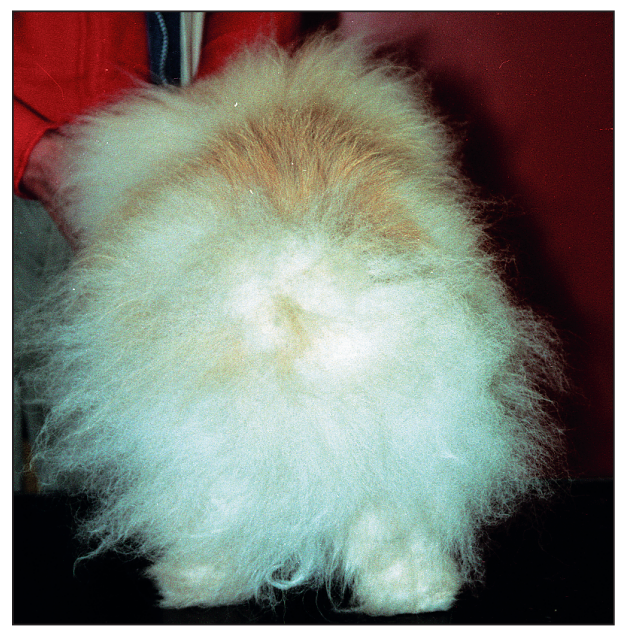

Fig. 5. Patient after mitotane therapy 